\title{
Nutrient turnover by freshwater bacterivorous flagellates: differences between a heterotrophic and a mixotrophic chrysophyte
}

\author{
Karl O. Rothhaupt* \\ Max-Planck-Institute for Limnology, Physiological Ecology Department, Postfach 165, D-24302 Plön, Germany
}

\begin{abstract}
The patterns of nutrient turnover by the freshwater bacterivorous chrysophycean flagellates Ochromonas sp. and Spumella sp. were compared in laboratory experiments. The exclusive phagotroph Spumella sp. released soluble reactive phosphorus (SRP) and ammonium when feeding on bacteria and stimulated the growth of P-limited algae, obviously by making phosphorus available to them. The mixotroph Ochromonas sp. released SRP and ammonium in the dark or at high bacterial densities in the light when phagotrophic nutrition prevailed, but it took up mineral nutrients when it grew primarily phototrophically. In P-limited situations, it retained bacterial P for its own photosynthetic growth and did not stimulate other phytoplankton. The results suggest basic differences in the patterns of nutrient turnover by mixotrophs and by exclusive phagotrophs.
\end{abstract}

KEY WORDS: Heterotrophic flagellate $\cdot$ Mixotrophic flagellate Chrysophyte $\cdot$ Bacterivory $\cdot$ Nutrient release $\cdot$ Nutrient uptake Laboratory experiment

\section{INTRODUCTION}

Aquatic bacteria are rich in nitrogen and phosphorus (Fagerbakke et al. 1996). For this reason and due to their abundance, bacteria can be an important pool of nutrients in the production zone of pelagic systems. Güde (1991) estimated that in the epilimnion of Lake Constance, the bacterial size fraction $(<1 \mu \mathrm{m})$ accounts for about $50 \%$ of the particulate phosphorus during the summer stratified season. Bacterial mortality therefore may result in significant mobilization and re-allotment of nutrients. Besides viruses, bacterivorous flagellates are usually seen as the main factor in bacterial mortality (Güde 1989). Nutrient mobilization by bacterivorous flagellates (e.g. Johannes 1965, Jürgens \& Güde 1990) as well as algal utilization of nutrients released by flagellates (e.g. Caron et al. 1988, Rothhaupt 1992) have been demonstrated experimentally.

\footnotetext{
- Present address: University of Konstanz, Limnological Institute, Postfach 5560, D-78434 Konstanz, Germany.

E-mail: karl.rothhaupt@uni-konstanz.de
}

Chrysophytes comprise a wide range of nutritional modes, ranging from chloroplast-bearing obligate phototrophs to nonpigmented phagotrophs (Sandgren 1988). Intermediate mixotrophic forms are able to combine phototrophic nutrition with the uptake of particular or dissolved organic material (Sanders \& Porter 1988, Sanders 1991). Members of the genus Ochromonas have been reported to be mixotrophs with limited photosynthetic capabilities. In some species or strains of Ochromonas photosynthesis is sufficient to run some maintenance metabolism at low bacterial densities, but not to grow actively (Fenchel 1982, Andersson et al. 1989). In contrast, the strain of Ochromonas used in this study has displayed considerable nutritional versatility in previous experiments (Rothhaupt 1996a). At one extreme, like an obligately heterotrophic flagellate, it was able to grow phagotrophically in the dark and released soluble nutrients. At the other extreme at low bacterial densities, it was able to adopt the functional role of phytoplankton, took up soluble nutrients and grew phototrophically in the light.

Mixotrophy, i.e. phagotrophy by photosynthetic organisms, has usually been seen as a strategy to use 
alternative carbon or energy sources, but the acquisition of nutrients other than $\mathrm{C}$ may also be important (Güde 1989). In fact, bacterivory of mixotrophic algae has been shown to increase when mineral nutrients are limiting (Nygaard \& Tobiesen 1993, Keller et al. 1994) and in marine field studies, abundances of mixotrophs were enhanced under conditions of nutrient limitation (Nygaard \& Tobiesen 1993, Arenovski et al. 1995). It is conceivable that some mixotrophs do not release excess bacterial nutrients (e.g. $N, P$ ) but retain them for additional photosynthetic carbon fixation when the concentrations of soluble nutrients are low. Exclusive phagotrophs, in contrast, have to release excess nutrients, at least those originating from the respired part of the ingested food. Consequently, the patterns of nutrient turnover mediated by mixotrophs and by obligate phagotrophs may differ.

The aim of the present study was to compare the nutrient dynamics of 2 freshwater bacterivorous chrysophycean flagellates, Spumella sp., an exclusive phagotroph and Ochromonas sp., a mixotroph that is able to obtain a significant part of its carbon metabolism from photosynthesis. The genera Spumella and Ochromonas apparently are closely related. They share the same functional morphology of the feeding apparatus and mainly differ in the lack or presence of a chloroplast (Fenchel 1986).

In laboratory experiments, I assessed the patterns of uptake and release of soluble mineral nutrients and tested whether phosphorus-limited phytoplankton were differently stimulated by the 2 grazers. I tested phytoplankton stimulation in a batch and in a chemostat experiment. In the batch experiment, there was no further input of soluble phosphorus and direct release by the grazers was the only mechanism to shift the limiting nutrient from bacteria to algae. In the dynamic equilibrium of the chemostats, bacteria and algae competed for the uptake of phosphate and 2 mechanisms mediated by bacterivores could possibly have affected the algae: direct phosphorus release by the grazers and reduced bacterial phosphorus uptake due to reduced bacterial numbers (Rothhaupt 1992).

\section{MATERIALS AND METHODS}

Organisms and standard conditions. Cultivation and experimentation were done in temperature-controlled rooms at $20 \pm 1{ }^{\circ} \mathrm{C}$. In all experiments, the light treatments received a photon supply of $\sim 100 \mu$ Einst $\mathrm{m}^{-2} \mathrm{~s}^{-1}$ in a light:dark rhythm of 16:8 h. All organisms were grown in WC (= MBL) medium (Guillard \& Lorenzen 1972). A mixed bacteria culture from a lakewater inoculum (filtered $<1 \mu \mathrm{m}$ ) was grown with $20 \mathrm{mg} \mathrm{l}^{-1}$ glucose as a carbon source. The bacterivorous flagel- lates and the coccale green alga Scenedesmus acutus were from the culture collection at the Max-PlanckInstitute in Plön, Germany. Spumella sp. (4 to $6 \mu \mathrm{m}$ diam.) was kept with food bacterid in wheat-grain cultures. Ochromonas sp. ( 6 to $8 \mu \mathrm{m}$ diam.) was cultured in the light with yeast extract $\left(-20 \mathrm{mg} \mathrm{l}^{-1}\right)$ as a carbon source (Rothhaupt 1996a). Scenedesmus acutus did not form coenobia but grew as single cells $(12$ to $15 \mu \mathrm{m}$ length, 4 to $5 \mu \mathrm{m}$ width). The oval-shaped phytoflagellate Cryptomonas sp. (12 $\mu \mathrm{m}$ length; 5 to $6 \mu \mathrm{m}$ width) was from the algal culture collection at the University of Göttingen, Germany (strain no. 26.80).

Nutrient release and uptake. Bacteria for this experiment were pregrown in medium with $20 \mathrm{mg} \mathrm{l}^{-1} \mathrm{glu}$ cose, but with reduced mineral nutrients $(4.8 \mu \mathrm{M}$ phosphate; $35.7 \mu \mathrm{M}$ ammonium nitrate). Hence, the nutrient stoichiometry $(\mathrm{C}: \mathrm{N}: \mathrm{P}=140: 15: 1)$ was such that the concentrations of soluble mineral nutrients were expected to be low after the bacteria had grown. The nutrient release and uptake experiment was done in 31 Erlenmeyer flasks with $1.5 \mathrm{l}$ bacterial suspension. Two controls without flagellates and 2 treatments with the mixotroph Ochromonas sp. were incubated in the dark and in a 16:8 h light:dark rhythm, respectively. Two flasks with the exclusive phagotroph Spumella sp. were also incubated in the light:dark rhythm. Several times per day, the flasks were shaken by hand. Samples for counting organisms and for measuring soluble mineral nutrients were taken every day in the morning, $2 \mathrm{~h}$ after the start of the light phase in the light:dark treatments.

Under the assumption that most of the dynamics of soluble nutrients was due to the flagellates and not the bacteria, I calculated soluble reactive phosphorus (SRP) and ammonium uptake rates (fmol cell ${ }^{-1} \mathrm{~d}^{-1}$ ) for daily intervals, using the equations of Heinbokel (1978).

Stimulation of P-limited phytoplankton. Stimulation of P-limited phytoplankton was tested in a batch and in a chemostat experiment. The batch experiment was done in $1 \mathrm{l}$ Erlenmeyer flasks with $750 \mathrm{ml}$ bacterial suspension. The bacteria had been pregrown in a medium with $1.6 \mu \mathrm{M}$ phosphate and no SRP was measurable in the bacterial suspension at the start of the experiment. The green alga Scenedesmus acutus served as a test organism and had been precultured to the stationary phase in low phosphate medium $(0.5 \mu \mathrm{M})$. Two controls received $S$. acutus (bacteria + algae), 2 flasks also received Ochromonas sp. (mixotroph + bacteria + algae) and 2 flasks also received Spumella sp. (phagotroph + bacteria + algae). All flasks were incubated in a 16:8 h light:dark regime and were shaken by hand several times per day. Samples for counting organisms and for measuring SRP were taken every day in the morning, $2 \mathrm{~h}$ after the start of the light phase. 


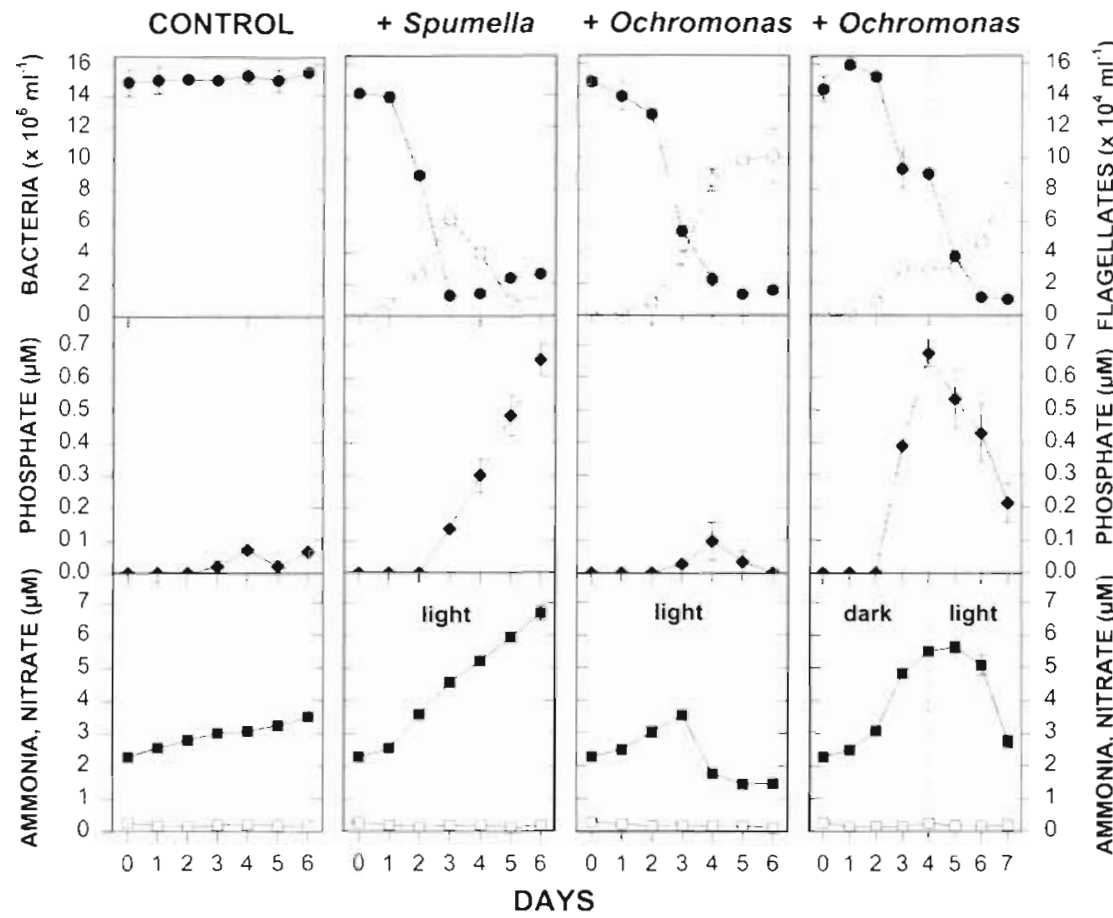

Fig. 1. Cell counts of bacteria $(\bullet)$ and flagellates $(0)$, and concentrations of phosphate $(\bullet)$, ammonium $(\square)$ and nitrite + nitrate $(\square)$ in the nutrient release and uptake experiment. Light indicates a diel light:dark rhythm of 16:8 h. Symbols give averages and ranges of 2 replicates ( 4 replicates for the control: 2 light +2 dark controls)

\section{RESULTS}

\section{Nutrient release and uptake}

Concentrations of soluble nutrients were low in the bacterial suspension at the start of the experiment. SRP was below detectability $(<0.03 \mu \mathrm{M})$, the concentration of nitrate + nitrite was $\sim 0.3 \mu \mathrm{M}$, and the ammonium concentration was $-2.2 \mu \mathrm{M}$ (Fig. 1). During the incubation, there was no difference between the control treatments in the light:dark regime and in the dark. In all controls, bacterial densities remained stable for $6 \mathrm{~d}$, SRP and ammonium concentrations increased slightly (Fig. 1).

Bacteria were reduced in all flagellate treatments. In the light: dark treatments with Spumella sp. as a grazer, SRP and ammonium concentrations increased strongly, signifying $P$ and $N$ release by the flagellates. There was no perceptible change in nitrate + nitrite concentrations (Fig. 1). Spumella sp.

In the chemostat experiment, Cryptomonas sp. was the phototroph. I have never observed bacterivory by this strain of Cryptomonas (Rothhaupt 1992). Three chemostats were run in parallel, supplied from the same reservoir with $\mathrm{P}$-limited medium $(1 \mu \mathrm{M}$ P). The chemostat vessels had a volume of $750 \mathrm{ml}$ and were operated at a dilution rate of $0.33 \mathrm{~d}^{-1}$. After Cryptomonas sp. and unidentified bacterial contaminants had successfully established populations in the chemostats, 1 reactor was inoculated with Ochromonas sp. and 1 with Spumella sp. The third one served as a control. Samples for counting organisms were taken daily.

Counting and chemical analyses. Samples for organism counts were fixed with formaldehyde $(2 \%$ final concentration) and subsamples were counted on black $0.2 \mu \mathrm{m}$ Nuclepore membranes by epifluorescence microscopy with diamidinophenylindole (DAPI) to stain bacteria and flagellates (Porter \& Feig 1980). Soluble mineral nutrients (phosphorus and nitrogen) were analyzed according to standard methods (Strickland \& Parsons 1972). numbers increased until Day 3. Changes in nutrient concentrations during this phase probably were due to nutrient release by actively growing flagellates (Fig. 2). After that, Spumella sp. numbers declined and increasing soluble nutrient concentrations most likely reflected release due to death and autolysis. $51 \%$ of the total ammonium release but only $20.6 \%$ of the total SRP release occurred during the first active growth phase of Spumella sp. (Fig. 2).

In the light:dark treatments with Ochromonas sp. as a grazer, the flagellates exhibited a sigmoid growth pattern (Fig. 1). There was no significant change in SRP

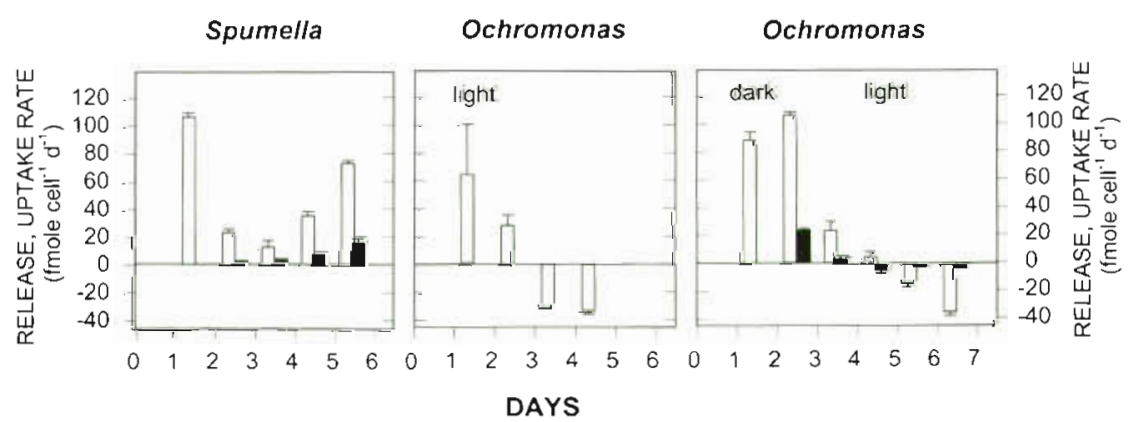

Fig. 2. Nutrient release and uptake rates calculated for daily intervals. Solid bars indicate SRP, open bars indicate ammonium release and uptake rates. Positive values (upward bars) signify release, negative values (downward bars) signify uptake 


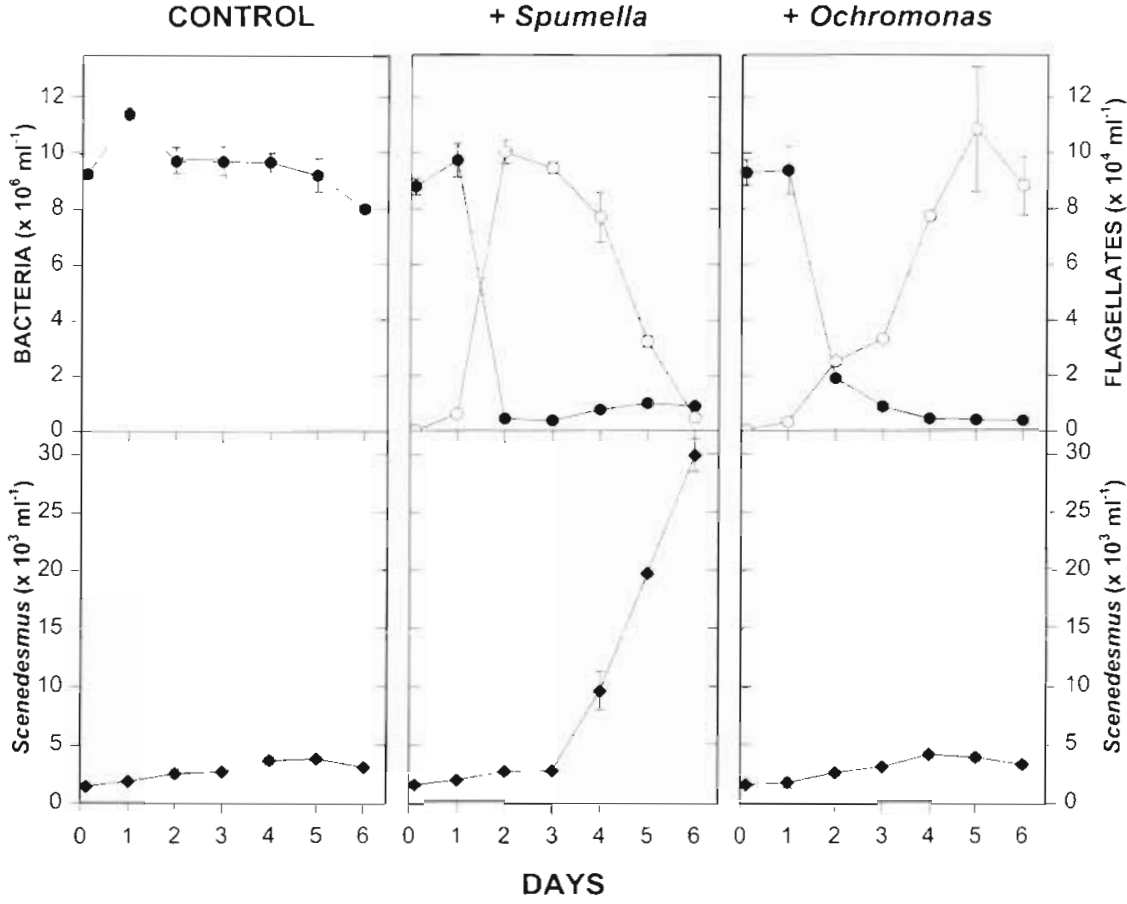

Fig. 3. Cell counts of bacteria $(\bullet)$, flagellates $(0)$ and Scenedesmus acutus $(\bullet)$ in the first phytoplankton stimulation experiment (batch culture, 16:8 h light:dark rhythm)

concentrations relative to the controls and consequently no SRP release or uptake rates could be detected (Fig. 2). Ammonium concentrations increased until Day 3 and afterwards declined (Fig. 1). Obviously, Ochromonas $\mathrm{sp}$. shifted from ammonium release in the first phase of the experiment to ammonium uptake afterwards (Fig. 2).

In the dark, when Ochromonas sp. was compelled to live solely phagotrophically, it released both SRP and ammonium (Fig. 1). Ammonium release rates were significant between Days 1 and 4, whereas SRP release was not detected before Day 2 (Fig. 2). Ochromonas sp. took up both nutrients when the dark flasks subsequently were exposed to the light:dark rhythm and flagellate growth resumed (Figs, $1 \& 2$ ).

\section{Stimulation of P-limited phytoplankton}

In P-limited batch cultures, the green alga Scenedesmus acutus responded differently to bacterial grazing by the phagotroph and the mixotroph. While $S$. acutus clearly increased in numbers after the third day in the Spumella sp. treatment, there was no such effect by Ochromonas sp. Although bacteria were grazed by the mixotrophs, the growth of $S$. acutus in these treatments was not different from the controls (Fig. 3). SRP concentrations remained low in all treatments and were not detectably raised after the flagellates had started to grow. P release by Spumella sp. was only evident from the growth response of $S$. acutus

In the chemostat experiment, no steady state was reached in the control treatment. Cryptomonas $\mathrm{sp}$. increased during the first $10 \mathrm{~d}$ and decreased afterwards while bacterial numbers grew even further (Fig. 4). The flagellates were inoculated on Day 11 and both Ochromonas sp. and Spumella sp. reduced bacterial numbers. Cryptomonas sp. densities remained unchanged in the presence of the mixotroph and increased in the presence of the obligate phagotroph (Fig. 4). This was evident from linear regressions of Cryptomonas sp. densities versus time for the interval from Day 11 to Day 25 (control:

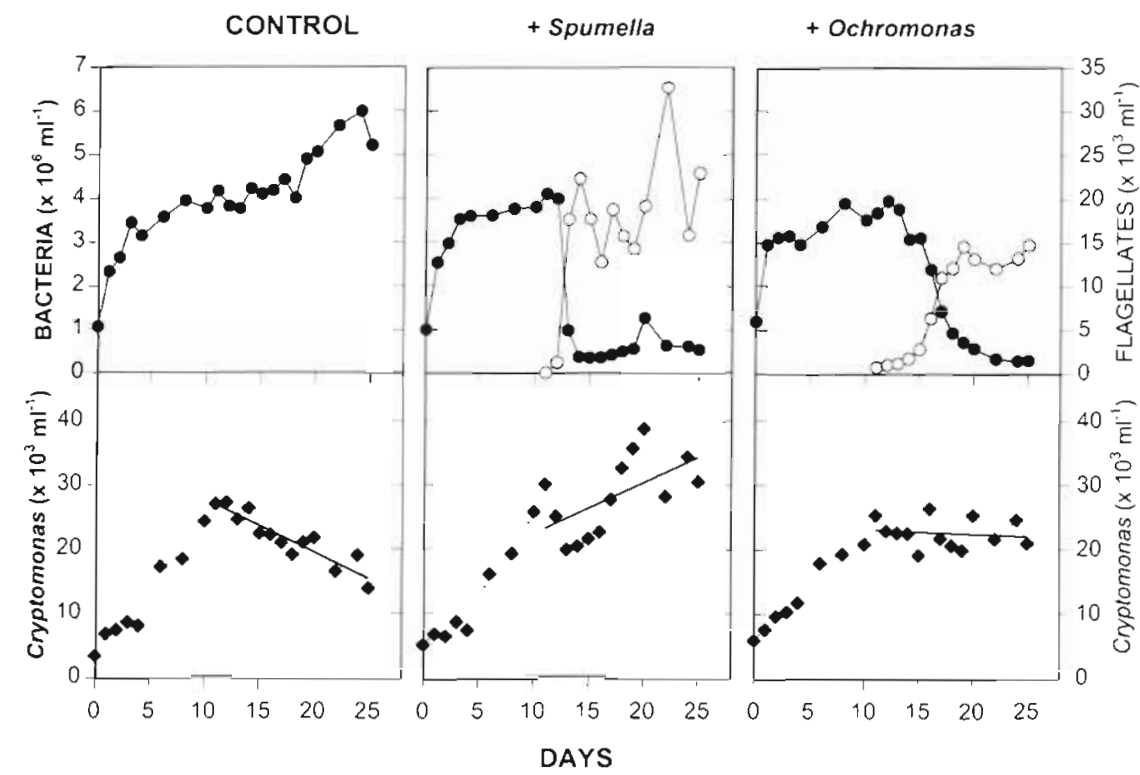

Fig. 4. Cell counts of bacteria (•), flagellates (0) and Cryptomonas sp. ( $\bullet$ in the second phytoplankton stimulation experiment (chemostat culture). To visualize the trends, linear regression lines of Cryptomonas sp. numbers versus time are plotted for the phase after the inoculation of flagellates (Days 11 to 25) 
slope $=-0.822, p<0.001 ;$ mixotroph treatment: slope $=$ 0.06 , not significant; phagotroph treatment: slope $=$ $0.793, p=0.03)$.

\section{DISCUSSION}

The results of the present study suggest that there are basic differences in the patterns of nutrient turnover by the mixotroph Ochromonas sp. and by the exclusive phagotroph Spumella sp. The phagotroph released SRP and ammonium and stimulated P-limited algae. The mixotroph released SRP and ammonium only in continuous darkness or at high bacteria densities in the light when phagotrophic nutrition prevailed, but it took up mineral nutrients when it grew primarily phototrophically. In P-limited batch cultures, subject to a daily light:dark rhythm, Ochromonas sp. retained bacterial $\mathrm{P}$ for its own photosynthetic growth and did not stimulate other phytoplankton. Under these conditions, the mixotroph obviously did not release phosphorus during the nocturnal dark phases but retained the nutrient intracellularly. Due to its photosynthetic capabilites, this strain of Ochromonas sp. is able to obtain a significant part of its carbon metabolism from photosynthesis and to grow actively when bacterial densities are low. In this situation it may use bacterial nutrients to meet the stoichiometric requirements of biomass production (Rothhaupt 1996a).

The situation appeared somewhat different in the chemostat experiment. There is a continuous input of the limiting nutrient, phosphate, into a P-limited mixed chemostat and algae and bacteria compete for the uptake (Currie \& Kalff 1984). In this dynamic system, the addition of bacterivores may have a 2 -fold stimulating effect for the phytoplankton. First, even without $P$ release by the grazers, the algae may benefit from decreasing bacterial phosphate uptake owing to reduced bacterial numbers and, second, as in the batch cultures with Spumella sp., the algae may take advantage of bacterial $P$ that is released by the grazers. Due to the lack of replication, the chemostat experiment does not offer unequivocal evidence. Nevertheless, it seems reasonable to assume that the divergent population trends of Cryptomonas sp. in the 3 treatments (decrease in the control, constancy in the presence of Ochromonas sp., increase in the presence of Spumella sp.) were due to the mechanisms mentioned. Both grazers diminished phosphate uptake by bacteria and Spumella sp. additionally mobilized bacterial P.

Bacterial carbon and photosynthetic carbon fixation are substitutable $\mathrm{C}$ sources as bacterial nutrients and soluble mineral nutrients are substitutable $P$ (and probably N) sources for this strain of Ochromonas sp. (Rothhaupt 1996a). This mixotrophic strategy was found to be bound up with costs and trade-offs for Ochromonas sp.: higher bacterial densities are needed to reach similar growth rates as specialized bacterial feeders and photosynthetic growth performance is reduced compared to algae of a similar size (Rothhaupt 1996a). On the other hand, the ability to use substitutable resources can give rise to interesting trophic interactions of mixotrophs with more specialized organisms. In laboratory experiments, Ochromonas sp. was able to coexist both with exclusively phagotrophic and with exclusively phototrophic competitors when either food bacteria or SRP were limiting and the alternative resource was also offered (Rothhaupt 1996b).

There is clear evidence from several authors in the literature that mixotrophy takes various forms for different species (reviewed by Sanders 1991). The mixotrophic spectrum comprises obligately phototrophic species like Dinobryon cylindricum that are unable to survive in continuous darkness (Caron et al. 1993) and predominantly phagotrophic species or strains like Poterioochromonas malhamensis that have sufficient photosynthetic capabilities to persist but not to grow actively at low bacterial densities in the light (Caron et al. 1990). Consequently, the patterns of nutrient turnover differ. In laboratory experiments, $D$. cylindricum was able to obtain 45 to $99 \%$ of the required nitrogen and phosphorus from ingested bacteria, the remainder probably was complemented by the uptake of soluble nutrients (Caron et al. 1993). In contrast, $P$. malhamensis was always a net mineralizer of bacterial nutrients and could not retain excess nutrients for later use while growing photosynthetically. The patterns of nutrient release by $P$. malhamensis were comparable to those by the exclusive phagotroph Spumella sp. in the present study (Caron et al. 1990).

Stoichiometric considerations suggest that the roles of bacterivorous mixotrophs, consumers or mineralizers of mineral nutrients, depend on the relative importance of photosynthetic carbon fixation. Bacterial nutrients are retained, and possibly complemented by the uptake of soluble nutrients, when photosynthesis constitutes a significant part of the carbon assimilation. Bacterial nutrients are released when phagotrophic nutrition prevails. The strain of Ochromonas used in this study was shown to be able to adopt both roles (Rothhaupt 1996a). In previous experiments, Ochromonas sp. released SRP when its growth was mainly phagotrophic, whereas it took up SRP when it shifted to predominantly photrophic growth and the uptake of bacterial phosphorus was not sufficient to meet the stoichiometric requirements. The present study shows that the same is valid for ammonium and furthermore that under conditions of low soluble nutrient concentrations, Ochromonas sp. is able to store bacterial nutrients for subsequent phototrophic growth. 
In nature, the relative abundance of chrysophytes, the phytoplankton group in which mixotrophy is most widespread, often increases in more oligotrophic situations (Sandgren 1988, Sommer et al. 1993). In some pre-alpine lakes, Dinobryon regularly occurs in late summer when seston stoichiometry suggests strong nutrient limitation (Dokulil \& Skolaut 1986, Sommer 1987). These patterns of occurrence may largely be due to the ability of some of these organisms to take up bacterial nutrients and to use them for their own photosynthetic growth. The stimulation of phytoplankton via nutrient release by phagotrophs obviously can be cut short by some mixotrophs and, in a way, take place within 1 organism that combines both roles.

Acknowledgements. Klaus Jürgens provided the flagellate cultures. Anita Bark, Heinke Buhtz and Ilka Senkpiehl helped with the nutrient analyses. Klaus Jürgens read an early draft of the manuscript and Nancy Zehrbach corrected the English.

\section{LITERATURE CITED}

Andersson A, Falk S, Samuelsson G, Hagström $\AA$ (1989) Nutritional characteristics of a mixotrophic nanoflagellate, Ochromonas sp. Microb Ecol 17:251-262

Arenovski AL, Lin Lim E, Caron DA (1995) Mixotrophic nanoplankton in oligotrophic surface waters of the Sargasso Sea may employ phagotrophy to obtain major nutrients. J Plankton Res 17:801-820

Caron DA, Goldman JC, Dennett MR (1988) Experimental demonstration of the roles of bacteria and bacterivorous protozoa in plankton nutrient cycles. Hydrobiologia 159: $27-40$

Caron DA, Porter KG, Sanders RW (1990) Carbon, nitrogen, and phosphorus budgets for the mixotrophic phytoflagellate Poterioochromonas malhamensis (Chrysophyceae) during bacterial ingestion. Limnol Oceanogr 35:433-443

Caron DA, Sanders RW, Lin Lim E, Marrasé C, Amaral LA, Whitney S, Aoki RB, Porter KG (1993) Light-dependent phagotrophy in the freshwater mixotrophic chrysophyte Dinobryon cylindricum. Microb Ecol 25:93-111

Currie DA, Kalff J (1984) Can bacteria outcompete phytoplankton for phosphorus? A chemostat test. Microb Ecol 10:205-216

Dokulil M, Skolaut C (1986) Succession of phytoplankton in a deep stratifying lake: Mondsee, Austria. Hydrobiologia 138:9-24

Fagerbakke KM, Heldal M, Norland S (1996) Content of carbon, nitrogen, oxygen, sulfur and phosphorus in native aquatic and cultured bacteria. Aquat Microb Ecol 10:15-27

Fenchel $T$ (1982) Ecology of heterotrophic nanoflagellates. II Bioenergetics and growth. Mar Ecol Prog Ser 8:225-231

Responsible Subject Editor: R. Sanders, Philadelphia, Pennsylvania, USA
Fenchel T (1986) The ecology of heterotrophic microflagellates. Adv Microb Ecol 9:57-97

Güde H (1989) The role of grazing on bacteria in plankton succossion. In: Sommer U (ed) Plankton ecology. Succession in plankton communities. Springer-Verlag. New York, p 337-364

Güde H (1991) Participation of bacterioplankton in epilimnetic phosphorus cycles of Lake Constance. Verh Int Ver Theor Angew Limnol 24:816-820

Guillard RRL, Lorenzen CJ (1972) Yellow-green algae with chlorophyllide C. J Phycol 8:10-14

Heinbokel JF (1978) Studies on the functional role of tintinnids in the Southern California Bight. I. Grazing and growth rates in laboratory cultures. Mar Biol 47:177-189

Johannes RE (1965) Influence of marine protozoa on nutrient regeneration. Limnol Oceanogr 10:434-442

Jürgens K, Güde H (1990) Incorporation and release of phosphorus by planktonic bacteria and phagotrophic flagellates. Mar Ecol Prog Ser 59:271-284

Keller MD. Shapiro LP, Haugen EM, Cucci TL, Sherr EB, Sherr BF (1994) Phagotrophy of fluorescently labeled bacteria by an oceanic phytoplankter. Microb Ecol 28: $39-52$

Nygaard K, Tobiesen A (1993) Bacterivory in algae: a survival strategy during nutrient limitation. Limnol Oceanogr 38 $273-279$

Porter KG, Feig YS (1980) The use of DAPI for identifying and counting aquatic microflora. Limnol Oceanogr 25 : 943-948

Rothhaupt KO (1992) Stimulation of phosphorus-limited phytoplankton by bacterivorous flagellates in laboratory experiments. Limnol Oceanogr 37:750-759

Rothhaupt KO (1996a) Utilization of substitutable carbon and phosphorus sources by the mixotrophic chrysophyte Ochromonas sp. Ecology 77:706-715

Rothbaupt KO (1996b) Laboratory experiments with a mixotrophic chrysophyte and obligately phagotrophic and phototrophic competitors. Ecology 77:716-724

Sanders RW (1991) Mixotrophic protists in marine and freshwater ecosystems. J Protozool 38:76-81.

Sanders RW, Porter KG (1988) Phagotrophic phytoflagellates. Adv Microb Ecol 10:167-192

Sandgren CD (1988) The ecology of chrysophyte flagellates: their growth and perennation strategies as freshwater phytoplankton. In: Sandgren CD (ed) Growth and reproductive strategies of freshwater phytoplankton. Cambridge University Press, Cambridge, p 9-104

Sommer $U$ (1987) Factors controlling the seasonal variation in phytoplankton species composition - a case study for a deep, nutrient-rich lake. Prog Phycol Res 5:123-178

Sommer U, Gaedke U, Schweizer A (1993) The 1st decade of oligotrophication in Lake Constance. 2. The response of phytoplankton taxonomic composition. Oecologia 93: $276-284$

Strickland JDH, Parsons TR (1972) A practical handbook of seawater analysis, 2nd edn. Bull Fish Res Bd Can 167

Manuscript first received: May 20, 1996

Revised version accepted: November 7, 1996 